\title{
NT Wright on justification: Faithfully embodying the reformed tradition of semper reformanda?
}

\section{INTRODUCTION}

This article seeks to examine N.T. Wright's theological contribution to the Reformed doctrine of Justification, with a view toward arguing that he is an important interpreter for and from the Reformed Tradition. An underlying question to be explored will concern what it means to stand faithfully and critically within the Reformed Theological Tradition. Given the Tradition's emphases upon "sola scriptura," and "semper reformanda," can we welcome the contributions and insights that Wright offers on the doctrine of justification? Or, must he be marginalized, at best, or anathematized, at worst, for failing to conform to the standard Reformed formulations found in our Confessions of faith? These questions are not easily answered because much controversy has surrounded Wright's statements concerning Justification - especially his denial, or re-defining, of the necessity of "Imputation," as historically understood within the Tradition. As we will see below, many Reformed thinkers have written against Wright's views of Justification, often viewing him as the latest manifestation of what is sometimes called the "New Perspective on Paul." This recent criticism has questioned Wright's theological orthodoxy and compelled him to clarify his position in the light of the Reformed Tradition. However, Wright claims to be a Reformed theologian in the sense that he has adopted the Reformers' method, even if not all of their conclusions. As we will see below, there are points of discontinuity with parts of the Reformed tradition in Wright's work. Yet, a close reading of his work also reveals many points of continuity, and thus may warrant the claim that Wright is working within the basic methodologies of the Reformed Tradition. If this is so, then Wright may be viewed as one who stands both faithfully (or, at least reliably) and critically within the Tradition - even as he proposes new interpretations of the New Testament and fresh articulations of Justification.

The $16^{\text {th }}$ century was an important time period in the process of defining and clarifying Christian doctrine. Some have considered the theological conclusions of the Protestant Reformers (such as Phillip Melanchthon and John Calvin ${ }^{1}$ ) and their immediate heirs (i.e. the "Reformed Scholastics") to be binding on all later Reformed tradition. However, others think that the Reformers' method is more important to emulate than their particular conclusions. This latter groups seeks to beware of the Reformed Confessions becoming a sort of cognate authority alongside Scripture itself, and thus compromising the Reformation conviction of sola scriptura. These also tend to view the Reformed tradition as "living" and open to fresh articulation - while remaining essentially faithful to the theological tradition that has been passed down.

\section{NT WRIGHT AS REFORMED THEOLOGIAN}

NT Wright ${ }^{2}$ considers himself a "Reformed Theologian" in the sense that he is committed to the Scriptures "alone" as that source wherein and whereby God exercises His authority. ${ }^{3}$ Wright firmly holds to the theological method of the Reformers but does not always agree with their conclusions. He writes,

\footnotetext{
"Ever since I first read Luther and Calvin, particularly the latter, I determined that whether
} 
or not I agreed with them in everything they said, their stated and practiced method would be mine too: to soak myself in the Bible, in the Hebrew and Aramaic Old Testament and the Greek New Testament, to get it into my bloodstream by every means possible, in the prayer and hope that I would be able to teach Scripture afresh to the church and the world. The greatest honour we can pay the Reformers is not to treat them as infallible-they would be horrified at that-but to do as they did." 4

In line with that aim, Wright makes use of the vast amount of historical research available to scholars today. Such resources were not as available to previous generations of theologians. Thus, one would suppose that biblical scholars and theologians today can have a clearer understanding of the historical context of the Bible. Thus, Wright believes this will inevitably affect our articulation of doctrine. In his section on "Rules of Engagement" in the recent book on Justification, Wright states, "We need to understand doctrines, their statement, development, confutation, restatement and so on, within the multiple social, cultural, political, and of course ecclesial and theological setting of their time." Likewise, a more accurate understanding of the biblical world helps us understand the literary tools of the ancient world. This can give a reader an advantage in properly grasping of themes and issues that the biblical writers were addressing. According to Wright, this should give current scholars a deeper understanding the bible than one who had only the words of Scripture and the statements of their traditions. In other words, it is not enough to simply know a biblical author's words. One must also be able to make proper inferences - which are usually historically and culturally conditioned. As a New Testament Scholar, we see Wright's commitment to text and context before doctrinal formulation in the following,
"we are bound to read the New Testament in its own first-century context... The more we know about first-century Judaism, about the Greco-Roman world of the day, about archaeology, the Dead Sea Scrolls and so on, the more, in principle, we can be on firm ground in anchoring exegesis that might otherwise remain speculative, and at the mercy of massively anachronistic exegesis, into the solid historical context where - if we believe in inspired Scripture in the first place - that inspiration occurred." ${ }^{5}$

And again, he writes, "We must read Scripture in its own way and through its own lenses, instead of imposing on it a framework of doctrine, however pastorally helpful it may appear, which is derived from somewhere else."6

Wright believes the Reformers were correct in much of their doctrinal formulation. However, they inevitably "under-understood" the text because they did not have adequate access to the world of the Bible. Instead, the Reformers formulated their doctrine in the fires of historical controversies far removed from the context of the bible itself. Therefore, Wright believes that historical research helps us do "sola scriptura" more faithfully than previous generations were capable of. And this should have a bearing on how we understand and articulate the Reformed Doctrine of Justification.

Before proceeding, some additional comment on Wright's self-understanding may be in order. He writes, "it may surprise you to learn that I still think of myself as a Reformed Theologian, retaining what seems to me the substance of Reformed theology while moving some of the labels around in obedience to Scripture-itself... a good Reformed sort of thing to do."7 Again he says,

"If I am simul justus et peccator, the church, not least the church as the Scripture-reading 
community, must be ecclesia catholica semper reformanda. Like Calvin, we must claim the right to stand critically within a tradition. To deny either of these would be to take a large step toward precisely the kind of triumphalism against which the Reformers themselves would severely warn us." 8

Here we see Wright appeal directly to the tradition of semper reformanda. He desires to stand within the Reformed tradition, but retain the right to be critical where he deems necessary.

Wright also asserts that when he began researching Paul in 1974, he made it his aim to study the text in line with his lifelong commitment to Scripture and to the sola scriptura principle. He says,

\begin{abstract}
"I was conscious of thereby standing methodologically in the tradition of the Reformers, for whom exegesis was the lifeblood of the church and who believed that Scripture should stand over against all human traditions. I have not changed in this aim and method, nor do I intend to...I believe that Luther, Calvin, and many others would tell us to read Scripture afresh, with all the tools available to us-which is, after all, what they did-and to treat their own doctrinal conclusions as important but not as important as Scripture itself. This is what I have tried to do, and I believe I am honouring them thereby." ${ }^{9}$
\end{abstract}

Here we see something of Wright's methodology. He understands his work as a continuation of what Luther and Calvin began - a tradition that would always be subject to our clearest possible understandings of Scripture.

\title{
SEMPER REFORMANDA
}

Ecclesia semper reformanda est is one of the valued tenets of the Reformed Tradition. The phrase itself is thought to emerge from the Nadere Reformatie movement within the $17^{\text {th }}$ century Dutch Reformed Church. The notion is referenced today by many in the global Reformed community. The idea is also sometimes used by those who seek to define and argue for a living Reformed Tradition. ${ }^{10}$ The idea of "always reforming" (or "always being reformed") refers to the belief that the church must continually re-examine itself in the light of Scripture in order to remain faithful to the text in both doctrine and living. ${ }^{11}$ The phrase may have first appeared in Jodocus van Lodenstein's, Beschouwinge van Zion (Contemplation of Zion, Amsterdam, 1674) ${ }^{12}$, though the notion seems to have been in use before then, given the work of the Reformers in challenging Roman Catholic Doctrine by appealing to Scripture. The full phrase is "The Church is reformed and always (in need of) being reformed according to the Word of God." Michael Horton points out that the verb is passive here. The church is not "always reforming," but is "always being reformed" by the Spirit of God through the Word of God. ${ }^{13}$

Those in the Reformed Tradition have aimed to embody this attitude and approach in forming both doctrine and life. The Protestant Reformers wanted to reform the church and its teaching according to the Scriptures. And Evangelicals prize their connection to Scripture as an essential identity marker. They would claim to be the people of "Sola Scriptura." However, some have been over-confident in the finality of the Reformed Standards (such as the Three Forms of Unity, The Augsburg Confession, and the Westminster Confession of Faith), such that the historical context of these documents has been down-played or ignored. In fact, many equate the Standards with "the faith once and for all delivered to the saints" (Jude 3). Therefore, no more significant theological work needs to be done - at least not at the basic level of exegesis. Horton's comments here are revealing. He states, 


\begin{abstract}
"We must always be open to correction from our brothers and sisters in other churches who have interpreted the Bible differently. Nevertheless, Reformed churches belong to a particular Christian tradition with its own definitions of its faith and practice. We believe our confessions and catechisms faithfully represent the system of doctrine found in Holy Scripture. We believe that to be Reformed is not only to be biblical; to be biblical is to be Reformed."14
\end{abstract}

However, the last part of this assessment seems to nullify the first part. There is a double-claim to be both open to others and embodying true biblical doctrine at the same time. To be fair, he later states that "those of us in the confessional Reformed churches must also beware of forgetting that our doctrinal standards are subordinate to the Word of God." ${ }^{15}$ N.T. Wright would readily agree and point out that this is exactly what he is doing, or attempting to do, through his own exegetical and theological work. The question is whether or not Wright is doing this as one who faithfully embodies the heart of the Reformed Tradition.

Horton wants to be careful that we do not make tradition infallible on the one hand. Yet on the other hand, he can state that "We don't need to move beyond the gains of the Reformation, but we do need further reformation (according to the Word of God). However, can these impulses co-exist? Can we codify the so-called "gains" of the Reformation as though they finally represent to us the authoritative interpretation of the text and also be open to any further reforming? It is unclear what needs further reformation. The question posed here is: Is there a place for scholarship, such as that reflected in the so-called "New Perspective on Paul," namely the form of which we find in Wright, in our ongoing need of reformation "according to the Word of God?"

\title{
THE DOCTRINE AND CONCEPT OF JUSTIFICATION
}

In discussing the doctrine of Justification, it is an important and helpful exercise to explore the history of the doctrine, with a focus upon the Reformed Tradition. This can enable us to offer informed reflections upon contemporary ecumenical opportunities and to consider the importance of new insights emerging from the so-called New Perspective on Paul. We must ask ourselves whether the Reformed Tradition is strengthened or threatened by the works of scholars like N.T. Wright. Another key question to be considered is whether the current debates on justification reveal a healthy living Reformed Tradition, or whether they reveal a static, defensive posturing that proves an underlying fragility. Surveying the history and noting the developments on this doctrine can help one track healthy continuities, which, in turn, can strengthen current dialogue, potentially reframing centuries-old dogma, but also potentially unifying once opposing churches within the one global "body" of Christ.

An essential resource is surveying the history of Justification is Alister McGrath's work, Iustitia Dei. Herein he makes an important point about the biblical "concept" of justification verses the historical "doctrine" of justification. He writes,

"The concept of justification and the doctrine of justification must be carefully distinguished. The concept of justification is one of many employed within the Old and New Testaments, particularly the Pauline corpus, to describe God's saving action toward his people. It cannot lay claim to exhaust, nor adequately characterize in itself, the richness of the biblical understanding of salvation in Christ." ${ }^{16}$

McGrath notes that the biblical concept of justification is not as all-encompassing as the later 
Reformed doctrine became. He goes on to suggest that the doctrine, in historical articulation, went beyond the biblical origins in terms of its definition:

"The doctrine of justification has come to develop a meaning quite independent of its biblical origins, and concerns the means by which man's relationship to God is established. The church has chosen to subsume its discussion of the reconciliation of man to God under the aegis of justification, thereby giving the concept an emphasis quite absent from the New Testament. The "doctrine of justification" has come to bear a meaning within dogmatic theology which is quite independent of its Pauline origins."17

This implies that quite early on the church began to deal with the concept of justification in abstracto, removing the ideas from their historical-theological contexts and applying the terms to the questions, struggles, and issues of their own times. For instance, one scholar has noted, "'The phrase [the imputation of Christ's righteousness] is not in Paul but its meaning is.' That is J.I. Packer, cautiously making the distinction between what Paul said and did not say and what Reformed theology, rightly in his view, can say in summarizing him."18

Further survey of the history of this doctrine goes beyond the scope of this paper. However, McGrath's important observation should be kept in mind as we think about forming and reforming theological traditions.

\section{TRADITION}

Closely connected to this study is the idea of tradition as a "living" reality. Jaroslav Pelikan has remarked, "Tradition is the living faith of the dead, traditionalism is the dead faith of the living." ${ }^{19}$ F.F. Bruce, commenting on the 1963 Fourth World Conference on Faith and Order, recognizes the helpfulness of a theological tradition in passing on beliefs to succeeding generations, but he also notes, "experience shows that there is a form of tradition which fossilizes the past and betrays its heritage." ${ }^{20} \mathrm{He}$ also adds that "the essence of reformation is the bringing of traditions into closer conformity with the Tradition," 21 the norm of which is Holy Scripture. Bruce believes that continuous reformation is necessary to prevent "fossilization" where, he notes, we may have otherwise had renewal. At the end of his book, Tradition Old and New, Bruce comments, "Let tradition and faith, church doctrine and church practice, canon and text, and the gospel narrative itself, be tested and validated by historical inquiry as far as such inquiry can take us: we shall be the gainers, not the losers."22

This insight can lead one to question whether the margins of Reformed orthodoxy are properly placed. Is it possible for the margins of doctrinal articulation, or "theological tradition," to be wide enough to include the findings and reflections of later scholars - namely, those who specialize in Biblical Studies and History? Or, is the tradition so solidified that any change in nuance or articulation is to be rejected as misguided, at best, or heretical, at worst? A final but significant question is; can these developments make Justification a unifying doctrine among all Christians - as it seems intended to be in Scripture - rather than the severely divisive doctrine it has been?

\section{NT WRIGHT ON JUSTIFICATION}

NT Wright had actually never published a book on the doctrine of Justification until recently. ${ }^{23} \mathrm{His}$ previous work touching the subject focused mainly on Paul's writings in the form of commentaries and books on Paul. Debates on justification within the Reformed community, mainly in the United 
States, began to look to and respond to Wright's exegesis and his seemingly new and/or radical expositions of justification. This was especially the case with the publication of John Piper's 2007 book, The Future of Justification: A Response to N.T. Wright. ${ }^{24}$. And so, Wright eventually laid out his doctrine in semi-systematic fashion, with all the underlying exegesis presented in support, in 2009, with his Justification: God's Plan \& Paul's Vision.

Although we cannot reproduce the whole argument here, we can summarize Wright's basic definitions of Justification, faith, righteousness, and imputation. ${ }^{25}$ He defines "justification" as,

"God's declaration, from his position as judge of all the world, that someone is in the right, despite universal sin. This declaration will be made on the last day on the basis of an entire life (Romans 2:1-16), but is brought forward into the present on the basis of Jesus' achievement, because sin has been dealt with through his cross (Romans 3:21-4:25); the means of this present justification is simply faith. This means, particularly, that Jews and Gentiles alike are full members of the family promised by God to Abraham." 26

We note a couple of observations. Justification retains its forensic aspect - so important to the Reformed tradition. In the present, justification has an eschatological horizon that is appropriated by faith ("simply faith" = "sola fide"?). Justification also rest upon the work of Christ. It is Christocentric and addresses the problem of sin. But there is also a corporate, horizontal aspect to Justification - namely the inclusion of both Jews and Gentiles into God's one people. This is also a "covenantal" aspect. Justification addresses who belongs to the Covenant people: The "righteous" people. These various aspects are expounded upon throughout Justification: God's Plan \& Paul's Vision.

In case one fears that this view will lead to some sort of "works righteousness," "Legalism" or Salvation by "works," Wright argues elsewhere (in commenting on Luke 17:1-10), "all we do, even the hard work we do for God, never for a moment puts God in our debt... all genuine service to God is done from gratitude, not to earn anything at all... we must constantly remind ourselves of the great truth: we can never put God in our debt." 27 Wright is often questioned at this point because he echoes the Pauline theme of final judgment according to works (Romans 2). But Wright insists that this is both a faithful reading of the New Testament and the result of a full understanding and belief in the work of the Holy Spirit (see Philippians 1:6). For his critics, this appears on the surface to draw sola fide, a definitive feature of Reformation theology, into question.

Wright's definition of "faith" draws both from the Gospels and the Pauline corpus. He does this intentionally because he believes that too much doctrinal assessment of the notion of "faith" has focused only on Paul (and perhaps James) while excluding Jesus' own use of the word. He writes,

"Faith in the New Testament covers a wide area of human trust and trustworthiness, merging into love at one end of the scale and loyalty at the other. Within Jewish and Christian thinking faith in God also includes belief, accepting certain things as true about God, and what he has done in the world... For Jesus, 'faith' seems to mean 'recognizing that God is decisively at work to bring the kingdom through Jesus.' For Paul, 'faith' is both the specific belief that Jesus is Lord and that God raised him from the dead (Romans 10:9) and the response of grateful human love to sovereign divine love (Galatians 2:20). This faith is, for Paul, the solitary badge of membership in God's people in Christ, marking them out in a way that Torah, and the works it prescribes, can never do."28 
In defining faith thus, Wright essentially ignores the medieval discussions and debates about the nature of "faith," and stays away from using the reformed term, "instrument." He also is not concerned to emphasize the passive/receptive nature of faith or limit it to "belief" or "trust" apart from loving, loyal action. He understands faith to be an active principle such that "faith" and faithfulness" have only the slightest thread between their meanings - if there is any difference at all. But note, Wright is still rejecting any notion of justification according to the works of Torah. The Jewish Law cannot be a basis for a Jew/Gentile Covenant People in Wright's thinking. Notice also that faith is directed primarily toward the Lordship of Jesus. This certainly includes Jesus' death and resurrection, but is not limited to those events. Those events establish his Lordship in an important sense. But Jesus as Lord is a present reality to be embraced, and not a historical fact to be affirmed. Thus, faith goes beyond affirming facts to living in relation to one who is presently reigning as the world's true king. This basic proclamation - the Jesus is Lord - is the summation of the gospel for Wright.

As for "righteousness," he writes that this word "denotes not so much the abstract idea of justice or virtue, as right standing and consequent right behaviour, within a community." ${ }^{29} \mathrm{He}$ notes that in both Hebrew and Greek the words "right," "righteous," "righteousness," "just," "justify," and "justification" all belong together linguistically and theologically. Wright explains how the Old Testament idea of righteousness comes from two merging settings - the lawcourt and the covenant. He writes, "To have 'righteousness' meant to belong to the covenant, the boundary marker of which was the Torah, and the hope of which was that God, in accordance with his own righteousness, would act in history to 'vindicate', to 'justify', his people (i.e. to show that they really were his people) by saving them from their enemies." He goes on, here and elsewhere, to show how "God's righteousness" refers not so much to his own moral virtue as to his "covenant faithfulness," that is, God's commitment to keep all his promises - certainly a righteous virtue in itself. But this is the basic meaning, according to Wright, in the minds of the Jewish people who read their scriptures and hoped in God. With regard to the people of God, the New Testament teaches that they do indeed have "righteousness." However, for Wright, this is not, strictly speaking, God's own righteousness. It refers to "the right standing of a member of the people of God. 'Righteousness' thus comes to mean, more or less, 'covenant membership', with all the overtones of appropriate behaviour." ${ }^{30}$ Wright makes the case that this is essentially what Paul means by these concepts whenever he uses them in his writings. Therefore, Wright appears to avoid a common medieval confusing, or blending, of the words "righteousness" and "merit."

This naturally leads to the issue of "imputation." Wright says,

"What, then, about the 'imputed righteousness'? This is fine as it stands; God does indeed 'reckon righteous' those who believe. But this is not, for Paul, the righteousness either of God or of Christ except in a very specialized sense... Only two passages can be invoked in favour of imputed righteousness being that of God or Christ. The first proves too much, and the second not enough." ${ }^{31}$

He is referring to 1 Corinthians 1:30-31 and 2 Corinthians 5:21. In the first, Wright believes the main point is about wisdom, not justification. In the latter, Wright exegetes this passage as pertaining to the Apostolic vocation of representing and proclaiming God's covenant faithfulness found in "the gospel" concerning Jesus, the Christ. ${ }^{32}$ He agrees that Romans 5:14-21 does indeed teach that there is a "reckoning of righteousness", but, again, this is not God's or Christ's own righteousness. It refers, rather, to "the fresh status of 'covenant member,' and/or 'justified sinner,' which is accredited to those who are "in Christ," who have heard the gospel and responded with 
'the obedience of faith.'"33 For Wright, imputation works more like this:

"Paul's doctrine of what is true of those who are in the Messiah does the job, within his scheme of thought, that the traditional Protestant emphasis on the imputation of Christ's righteousness did within that scheme. In other words, that which imputed righteousness was trying to insist upon is, I think, fully taken care of in (for instance) Romans 6, where Paul declares that what is true of the Messiah is true of all his people. Jesus was vindicated by God as Messiah after his penal death; I am in the Messiah; therefore I, too, have died and been raised. According to Romans 6, when God looks at the baptized Christian, God sees him or her in Christ. But Paul does not say that God sees us clothed with the earned merits of Christ. That would be the wrong meaning of 'righteous' or 'righteousness.' He sees us within the vindication of Christ, that is, as having died with Christ and risen again with him. I suspect that it was the medieval overconcentration on righteousness, on justitia, that caused the Protestant Reformers to push for imputed righteousness to do the job they rightly saw was needed. But in my view, they have thereby distorted what Paul himself was saying." 34

From this we can see that Wright thinks it more biblically faithful to think of the death and resurrection of Christ being "imputed" to believers than to think of any sort of "active obedience," law-keeping, or merit of Christ being imputed as a basis for justification. Again, he writes, "when we bring the doctrine of 'imputed righteousness' to Paul, we find that he achieves what that doctrine wants to achieve, but by a radically different route. In fact, he achieves more. To know that one has died and been raised is far, far more pastorally significant than to know that one has, vicariously, fulfilled the Torah." ${ }^{35}$ To continue thinking along the lines of the confessional Reformed tradition, which makes the active obedience of Jesus (often equated with "Christ's righteousness") being imputed to believers the necessary basis of Justification, would seem to make Jesus the ultimate legalist and Judaism (or the Old Testament) really about law-keeping rather than grace and covenant. ${ }^{36}$

Wright re-emphasizes these points, providing important notes of clarity, in his recent book on Justification. There is, in fact, not really anything "new" in this work. Rather, he takes the same points he has made again and again in other places, such as those cited above, and puts them into a semi-systematic argument. Therein he not only provides a solid overview of the doctrine according to his reading of Paul, he also provides a long section on the exegetical basis for this articulation of justification - digging deeply into the relevant New Testament passages in Romans, Galatians, Philippians, Corinthians, and Ephesians. More than that, he shows how Paul's "gospel" - which includes justification - sees the entire biblical narrative finding it's fulfilment in the person and work of Jesus. One finds this work to be very clear, and the argument compelling. In it, as we have already seen, Wright stresses three key dimensions of the Pauline account of Justification: the lawcourt, the covenant, and eschatology, weaving them together in a way that he sees as biblically consistent, theologically faithful, and pastorally sufficient. He summarizes his overall view of Paul's doctrine of justification as follows;

"Paul believed, in short, that what Israel had longed for God to do for it and for the world, God had done for Jesus, bringing him through death and into the life of the age to come. Eschatology: the new world had been inaugurated! Covenant: God's promises to Abraham had been fulfilled! Lawcourt: Jesus had been vindicated - and so all those who belonged to Jesus were vindicated as well! And these, for Paul, were not three, but one. Welcome to Paul's doctrine of justification, rooted in the single scriptural narrative as he read it, 
This overview gives us much to think about. We can see that Wright believes he is moving in a biblically faithful way. Therefore, his work should arguably be considered worthy of our consideration in our theological development - as a tradition that aims to embody the semper reformanda principle. As Wright states, "if the church is to be built up and nurtured in Scripture it must be semper reformanda, submitting all its traditions to the Word of God." 38

At times it seems as if Wright finds it difficult to answer questions from those in the Reformed community, especially those who serve as pastors. There seems to be a struggle to answer questions wherein he thinks it necessary to disassemble certain presuppositions and theological constructs in order to reframe them in a more "biblical" way, and then to provide an answer that will make sense. He is often working from a different biblical or theological framework than his critics, such that direct answers are not always possible. This requires patience and a willing openness to follow his argument all the way through.

\section{REFORMED RECEPTION OF WRIGHT}

It is good and right that those representing the Reformed tradition should put Wright's claims to serious and sustained scrutiny. He does appear at odds with some long-held and established beliefs in the Reformed Tradition. And certainly not everyone in the Reformed community has agreed with Wright's exegesis or his articulation of Justification. One could look to the published results of the study committees formed by both the Presbyterian Church in America (2007) and the Orthodox Presbyterian Church (2006) as two examples of whole church bodies considering and rejecting the claims of both the New Perspective on Paul (or "NPP) and N.T. Wright on Justification. ${ }^{39}$ One can also find many articles critiquing either the New Perspective and/or N.T. Wright online. ${ }^{40}$ Those who have questioned or attempted to refute the NPP or Wright have come from many denominational backgrounds, but mostly they are from within the Reformed tradition. Some of the most vocal critics have included: D.A. Carson, Mark Seifrid ${ }^{41}$, Guy Prentiss Waters ${ }^{42}$, Stephen Westerholm ${ }^{43}$, Thomas Schreiner ${ }^{44}$, Seyoon Kim ${ }^{45}$, Ligon Duncan ${ }^{46}$, Andrew Das $^{47}$, and John Piper ${ }^{48}$. There are many others, but these arguably represent the most influential scholarly detractors. ${ }^{49}$

Demonstrating the importance of Wright's work and the seriousness with which his critics have responded, The Southern Baptist Theological Seminary hosted a panel discussion on "N.T. Wright and the Doctrine of Justification"50 in the Fall of 2009. They claimed that Wright's view of justification was defective and unbiblical. However, there was no direct engagement with Wright's exegesis, only appeals to traditional beliefs. They suggested that if Wright was correct, then the very gospel itself was at stake. At one point, a commentator noted that Wright was "Biblicistic," such that if one wanted to disagree with him one would have to use the Bible to do so. This was the odd criticism of a Southern Baptist scholar, even though they are not known for having "confessional" commitments.

In similar fashion, the February 2010 edition of Tabletalk ${ }^{51}$, put out by Ligonier Ministries, brought together a group of 13 Reformed theologians to write against small excerpts from Wright's writings. ${ }^{52}$ The defensive posturing appeared radical enough to suggest a real threat to Reformed orthodoxy.

At the same time, not everyone connected to the Reformed Tradition has been so critical of Wright. Michael Bird, a "card carrying Calvinist who is committed to the Reformed tradition," 53 has a special section in his work, The Saving Righteousness of God, where he addresses the controversy surrounding Wright. In it he makes an appeal to modern scholars to "affirm the 
value of Wright as an interpreter from and for the reformed tradition." 54 He also seeks to "defend a generation of young scholars and pastors who remain appreciative of his work and wish to remain in dialogue with him." 55 Similarly, one of Evangelicalism's most esteemed theologians, J.I. Packer has said, "Brilliant Bishop Wright is one of God's best gifts to our decaying Western church". And other scholars, such as Don Garlington, Kent Yinger, Douglas Campbell, Scot McKnight, Richard Hays, Kevin Vanhoozer and Bruce Longenecker ${ }^{56}$ have supported and affirmed aspects of Wright's work on Justification. In all of this we see that issues are important and that the responses on both sides, whether agreeing or disagreeing with Wright, have been numerous.

\section{CONCLUSIONS}

Given the recent and historic debates on Justification, and the fact that no historic answer has caused these debates to end, it may not be unreasonable to suggest that Reformed churches call for more and better-informed communication on this topic (such as that demonstrated in 2010 at the Wheaton Theology Conference and the US national meeting of the Evangelical Theological Society, both of which hosted Wright and conversed charitably with him and his views). Perhaps the debates are signal that the time is ripe for fresh articulations of these doctrines in light of our own times and informed by the contributions of more recent scholarship, worship, devotion, and critical thought. We should certainly never lose sight of the important doctrinal discoveries of the Reformed theological heritage, but we should also be open to fresh illumination from God's Holy Spirit at work in Christ's Church.

Some good ecumenical work has already been done on the doctrine of Justification. The 1999 Joint Declaration on the Doctrine of Justification ${ }^{57}$ from The Lutheran World Federation and The Roman Catholic Church is one important example. An important question is, however, can "Reformed" Christians continue the conversation, with winsome intelligence and patience? And can Wright's version of Justification - and his so-called "Fresh" perspective on Paul - be brought to the table for our fair consideration?

In light of what we have seen above, one can argue that a close reading of Wright's work warrants the claim that he can be viewed within the Reformed tradition. One can argue that Wright is faithfully embodying the Reformed notion of semper reformanda by calling the traditional dogmas into question, reframing the answers according to biblical exegesis, and maintaining the essential methodology of our Magisterial Reformers, imitating faithfully what they began - which was to go to the Bible and examine all doctrine in its light. Wright's argument is presented in a very clear and compelling manner, and we should not fail to take his work seriously, especially given his commitment to the principles outlined above. We have a responsibility to seriously engage his work with an openness that comes from our shared methodology, and let the conclusions fall where they may. Wright maintains some of the valued aspects of the Reformed doctrine despite the points of discontinuity. Justification is still regarded as a forensic declaration. It is still rooted in the work of Christ and regarded as a benefit of incorporation into Christ. He also affirms that those who are justified are so by faith and not by works of the Jewish Law. But he is more emphatic that the "law" addressed by Paul refers to the Jewish Law and not to morality in general. Wright also more clearly connects the biblical concept of with its historical context in asserting that justification addresses the Covenant community, both Jew and Gentile, and thus has an important horizontal dimension. Finally, Wright believes that the eschatological aspect of Justification has been overlooked and deemphasized in the Reformed Confessional tradition. By "eschatological" Wright means that justification has both a present and future aspect. They are not disconnected, however. Present justification is always by faith (this is the mark of those truly declared "righteous" by faith in Christ), but future justification 
includes a consideration of one's works (or, obedience). Wright does not think this constitutes a double grounds for justification, but rather that the future judgment is essentially guaranteed by the internal presence of the Holy Spirit within believers. The works that are affirmed at the final judgment are produced by the Spirit. The future vindication is broad backwards, as it were, into the present to be enjoyed as if the verdict had already occurred. Wright believes a faithful exposition of the fullness of Scripture requires such a dynamic to be part of our doctrine of Justification. These points encourage Reformed theologians today to remain in dialogue with Wright about Justification and its related concepts. His commitment to the texts of Scripture, and much of the theological tradition, is a shared value that can help us continue to engage his work enthusiastically and optimistically.

As we have argued here, the Reformed Tradition is strong enough to welcome the insights of Wright into its theological prevue. As R.W.A. Letham has commented, "Reformed Theology is not, nor has (it ever) been, monolithic. It has possessed the creative vitality sufficient to encompass diversity within an over-all consensus." ${ }^{58}$ In other words, the Tradition is dynamic and living. Just as the various Reformed Confessions show diversity in the articulation of some doctrines, the Tradition may be enriched by Wright's contributions in such a way as to encourage continual development - in light of Scripture. My hope is that Reformed Churches can appreciate, welcome, and intelligently dialogue with Wright, and thus demonstrate Letham's statement to be true. The other side of that hope is that this will prevent Reformed doctrine from becoming so solidified and authoritative as to prematurely determine "heretics," and push many faithful theologians out of the church. I seek to argue all of this is in effort to prevent the Reformed tradition from leaving one of its finest principles, semper reformanda, which can be a guiding light in the midst of the darkness of a rigid and dead traditionalism.

\section{(ENDNOTES)}

1 Calvinsim" is often used as a synonym for Reformed Theology because of John Calvin's influence in shaping the theology coming out of the Protestant Reformation. It should be noted, however, that the synonymity can be taken too far. Calvin is not the only source of all things "Reformed."

2 N.T. Wright (sometimes published as "Tom Wright") is a distinguished Professor of New Testament at St. Andrews University. He has taught New Testament studies at some of the world's most prestigious universities (Oxford and Cambridge). He also recently served as the Anglican Bishop of Durham for 7 years. He was once the Canon Theologian of Westminster Abbey. He is a noted scholar whose influence and readership literally span the globe.

3 See N.T. Wright, The Last Word: Scripture and the Authority of God- Getting beyond the Bible Wars, (San Francisco: HarperCollins, 2005).

4 N.T. Wright, Justification: God's Plan \& Paul's Vision, (Downers Grove: Inter-Varsity Press, 2009), 22-23.

5 Wright, Justification, 46-47.

6 Ibid., 233.

7 N.T. Wright, "New Perspectives on Paul," in McCormack, Bruce L., ed, Justification in Perspective, (Grand Rapids: Baker Academic, 2006), 263.

8 Ibid., 247-248.

9 Ibid., 244.

10 For instance, see Brian Gerrish, "Tradition in the Modern World: The Reformed Habit of Mind," in Toward the Future of Reformed Theology: Tasks, Topics, Traditions, eds. David Willis and Michael Welker, (Grand Rapids: Eerdmans, 1999), 3-20, and Robert Vosloo, "Reforming 
Tradition?" in the Journal of Theology for Southern Africa 139 (March 2010), 19.

11 For a short summary, from which this section draws, see "Ecclesia semper reformanda est" at http://www.tutorgig.info/es/semper+reformanda.

12 See Michael Bush, "Calvin and the Reformanda Sayings," in Herman J. Selderhuis, ed., Calvinus sacrarum literarum interpres: Papers of the International Congress on Calvin Research (Göttingen: Vandenhoeck \& Ruprecht, 2008) p. 286.

13 Michael Horton, "Semper Reformanda", Tabletalk Magazine. October 1, 2009. http://www. ligonier.org/learn/articles/semper-reformanda/

14 Ibid.

15 Ibid.

16 Alister McGrath, Iustitia Dei: A History of the Christian Doctrine of Justification from 1500 to the Present Day, (Cambridge: Cambridge University Press, 1986), 1:2.

17 Ibid., 1:2-3.

18 Wright, Justification, 46. The Packer quotation is from his article "Justification," in the New Bible Dictionary, ed. J.D. Douglas, (London: Inter-Varsity Press, 1962), 685.

19 Jaroslav Pelikan, The Vindication of Tradition (Yale University Press, 1984).

20 F.F. Bruce, Tradition: Old and New, 171. See also The Fourth World Conference on Faith and Order, ed. P.C. Rodger and L. Vischer (London, 1964).

21 Ibid, 172.

22 Ibid. 173.

23 N.T. Wright, Justification: God's Plan \& Paul's Vision, (Downers Grove: InterVarsity Press, 2009).

24 John Piper, The Future of Justification: A response to N.T. Wright, (Wheaton: Crossway, 2007).

25 For a thorough and full explanation of Wright's understanding of Justification, he lays it out in Justification, 80-108, which concludes Part One of his work. Part two extensively provides the exegetical basis of Part One.

26 Tom Wright, Paul for Everyone: Romans: Part One, (Westminster John Knox Press, 2004), 169-170. See also Sinclair Ferguson, David F. Wright, and J.I. Packer, eds, New Dictionary of Theology, (Downers Grove: Inter-Varsity Press, 1988), 359-361.

27 Tom Wright, Luke For Everyone, (Westminster John Knox Press, 2001), 204.

28 Ibid., 167.

29 Ibid., 591. See also NDT, 590-592. Wright also contributes the articles on "Jesus" and "Paul."

30 Ibid., 592.

31 N.T. Wright, "New Perspectives on Paul," in McCormack, Bruce L., ed, Justification in Perspective, (Grand Rapids: Baker Academic, 2006), 252.

32 For Wright's discussion on these passages from the Corinthian correspondence, see Wright's comments in Justification: God's Plan \& Paul's Vision, 153-166.

33 Wright, "New Perspectives on Paul," 253.

34 Ibid., 260-261. This view of participation in Christ has been called by Wright and others "incorporated righteousness." See Michael F. Bird, The Saving Righteousness of God: Studies on Paul, Justification and the New Perspective, Paternoster Biblical Monographs, (Eugene, OR: Wipf \& Stock, 2007).

35 Wright, Justification, 233. This statement occurs in the exegetical section of Romans. Before this he states "It is not the 'righteousness' of Jesus Christ which is 'reckoned' to the believer. It is his death and resurrection." 232-233.

36 For more on the nature of Second Temple Judaism and the relationship of grace, obedience, 
and covenant, see E.P. Sanders, Paul and Palestinian Judaism: A Comparison of Patterns of Religion, (Philadelphia: Fortress, 1977), especially 33-428. This work forced a re-evaluation of the kind of Judaism to which both Jesus and Paul were responding.

37 Wright, Justification, 101.

38 Ibid., 233.

39 For the PCA report see http://www.pcahistory.org/pca/07-fvreport.html. For the OPC report see http://www.opc.org/GA/justification.pdf .

40 See www.monergism.com/directory/link category/New-Perspective-on-Paul/GeneralEssays-Critiquing-NPP. For a comprehensive list of works supporting and/or simply related to these issues, see www.thepaulpage.com.

41 See D.A. Carson, P.T. O’Brien and Mark A. Seifrid, Justification And Variegated Nomism, 2Vols (Grand Rapids: Baker Academic, 2001, 2004). See also Mark Husbands and Daniel J. Treier, eds., Justification: What's at Stake in the Current Debates (Leicester, England: Apollos, 2004), and Mark A. Seifrid, "The 'New Perspective on Paul' and its Problem," Them 25 (2000): 4-18.

42 See Guy Prentiss Waters, Justification and the New Perspectives On Paul: A Review And Response (Phillipsburg, NJ,: P\&R Publishing, 2004).

43 See Stephen Westerholm, Perspectives Old and New on Paul: The "Lutheran" Paul and His Critics (Grand Rapids, MI: Eerdmans, 2003).

44 See Thomas R. Schreiner, "Paul and Perfect Obedience to the Law: An Evaluation of the view of E. P. Sanders," WTJ 47 (1985): 245-78, and The Law and Its Fulfillment: A Pauline Theology of Law (Grand Rapids, MI: Baker, 1993).

45 See Seyoon Kim, Paul and the New Perspective: Second Thoughts on the Origin of Paul's Gospel (Grand Rapids, MI: Eerdmans, 2002).

46 See J. Ligon Duncan, Misunderstanding Paul? Responding to the New Perspectives (Wheaton, IL: Crossway, 2005).

47 See A. Andrew Das, Paul, the law, and the Covenant (Peabody, MASS: Hendrickson Publishers, 2001).

48 See John Piper, Counted Righteous in Christ: Should We Abandon the Imputation of Christ's Righteousness? (Wheaton, IL: Crossway, 2002), and The Future of Justification: A Response to N.T. Wright (Wheaton, IL: Crossway, 2007).

49 In North America and Great Britain, that is.

50 See http://www.sbts.edu/resources/chapel/chapel-fall-2009/panel-nt-wright-and-the-doctrine-of-justification-2/ . and see also http://news.sbts.edu/2009/09/04/wrights-view-of-justification-is-defective-and-unbiblical-sbts-panelists-say/. The panel was positive toward Wright and his contributions to New Testament Scholarship in parts of their discussion. However, their criticism became rather acute as it progressed.

$51 \mathrm{http}: / / w w w . l i g o n i e r . o r g / b l o g / c o l u m n s-t a b l e t a l k-m a g a z i n e-f e b r u a r y-2010 /$ and also http:// www.ligonier.org/learn/keywords/nt-wright/

52 It is revealing of the depth of the perceived threat to orthodoxy which Wright represents that such a group of Reformed theologians would gather together to undermine the work of a single New Testament Scholar.

53 Michael Bird, The Saving Righteousness of God: Studies on Paul, Justification, and the New Perspective, (Eugene, OR: Wipf \& Stock Publishers, 2007), 183-184.

54 Ibid., 184.

55 Ibid.

56 See Don Garlington, In Defense of the New Perspective on Paul: Essays and Reviews, (Eugene, OR: Wipf \& Stock, 2005; Kent L. Yinger, Paul, Judaism, and Judgment According to 
Deeds, SNTSMS 105. (Cambridge University Press, 1999); Douglas A. Campbell, The Quest for Paul's Gospel: A Suggested Strategy. JSNTSup 274, (London: T \& T Clark, 2005); Scot McKnight- see endorsement for N.T. Wright, Justification, 2009; Richard B Hays- see also endorsement for Wright, Justification, Kevin Vanhoozer, "Wrighting the Wrongs of the Reformation: The State of the Union with Christ in St. Paul and Protestant Soteriology," in Jesus, Paul, and the People of God: A Theological Dialogue with N.T. Wright, ed., Nicholas Perrin and Richard B. Hays, (Downers Grove, IL: IVP Academic, 2011); and Bruce W. Longenecker, The Triumph of Abraham's God: The Transformation of Identity in Galatians, (Nashville: Abingdon, 1998). 57 See the Joint Declaration on the Doctrine of Justification by the Lutheran World Federation and The Roman Catholic Church, (Grand Rapids: Eerdmans, 2000). 58 R.W.A. Letham, "Reformed Theology,” NDT, 570.

\section{BIBLIOGRAPHY}

Joint Declaration on the Doctrine of Justification by the Lutheran World Federation and The Roman Catholic Church, Grand Rapids: Eerdmans, 2000.

Bird, Michael, The Saving Righteousness of God: Studies on Paul, Justification, and the NewPerspective, Eugene, OR: Wipf \& Stock Publishers, 2007.

Bruce, F.F. Tradition: Old and New, 171. See also The Fourth World Conference on Faith and Order, ed. P.C. Rodger and L. Vischer, London, 1964.

Bush, Michael, "Calvin and the Reformanda Sayings," in Herman J. Selderhuis, ed., Calvinus sacrarum literarum interpres: Papers of the International Congress on Calvin Research, Göttingen: Vandenhoeck \& Ruprecht, 2008.

Fesko, J.V. "The New Perspective on Paul: Calvin and N. T. Wright", Banner of Truth, 2003.

Horton, Michael, "Semper Reformanda", Tabletalk Magazine. October 1, 2009. http://www.ligonier.org/ learn/articles/semper-reformanda/

Letham, R.W.A. "Reformed Theology," in New Dictionary of Theology, ed. David F. Wright et al. Downers Grove, IL: InterVarsity Press, 1988, 570.

McGrath, Alister, Iustitia Dei: A History of the Christian Doctrine of Justification from 1500 to the Present Day, Cambridge: Cambridge University Press, 1986.

Pelikan, Jaroslav, The Vindication of Tradition, Yale University Press, 1984.

Piper, John. Counted Righteous in Christ. Wheaton, II: Crossway, 2002.

Piper, John The Future of Justification: A Response to N.T. Wright. Wheaton, IL: Crossway, 2007.

Wright, N. T. What St. Paul Really Said, Oxford, 1997.

.Justification: God's Plan \& Paul's Vision. Downers Grove, IL: InterVarsity Press, 2009.

Simply Christian: Why Christianity Makes Sense. HarperSanFrancisco, 2006.

Evil and the Justice of God. IVP Academic. 2006.

Paul: Fresh Perspectives. Minneapolis: Fortress, 2005.

The Last Word: Beyond the Bible Wars to a New Understanding of the Authority of Scripture.

HarperOne, 2005.

Jesus and the Victory of God. Christian Origins, vol. 2. Minneapolis: Fortress, 1996.

Following Jesus: Biblical Reflections on Discipleship. Eerdmans, 1997.

The New Testament and the People of God. Christian Origins, vol. 1. Minneapolis: Fortress, 1992.

The Resurrection of the Son of God. Christian Origins, vol. 3. Minneapolis: Fortress, 2003.

1991.

The Climax of the Covenant: Christ and the Law in Pauline Theology. Edinburgh: T\&T Clark Fortress,

The Letter to the Romans, in The New Interpreter's Bible, Vol X. Nashville: Abingdon Press, 2002.

Paul for Everyone: Galatians and Thessalonians. Louisville: Westminster John Knox, 2004.

Paul for Everyone: Romans: Part One, Westminster John Knox Press, 2004.

Luke For Everyone, Westminster John Knox Press, 2001.

Wright, N.T. "4QMMT and Paul: Justification, 'Works', and Eschatology," in History and Exegesis: New Testament Essays in Honor of Dr. E. Earle Ellis for His 80th Birthday, ed. Aang-won Son. New York and London: T\&T Clark, 2006. 
"New Perspectives on Paul" in Justification in Perspective: Historical Developments and Contemporary Challenges, ed. Bruce L. McCormack. Grand Rapids: Baker Academic, 2006, 243-264.

"On Becoming the Righteousness of God," in Pauline Theology, Volume II: 1 \& 2 Corinthians, ed.

David M. Hay. Minneapolis: Fortress, 1993, 200-208.

"Righteousness," in New Dictionary of Theology, ed. David F. Wright et al. Downers Grove, IL: InterVarsity Press, 1988, 590-592.

"Justification." in New Dictionary of Theology, ed. David F. Wright et al. Downers Grove, IL: InterVarsity Press, 1988, 359-361.

"The Shape of Justification" (2001), http://www.thepaulpage.com/Shape.html. "Ecclesia semper reformanda est," at http://www.tutorgig.info/es/semper+reformanda

\section{KEY WORDS \\ Justification \\ Reformed \\ Tradition \\ Calvin \\ Edwards \\ Wright}

Contact Details:

Rev. Jonathan Huggins

Chaplain and Pastor

Berry College

Mount Berry Church

jhuggins@berry.edu

706-378-2878- office

706-254-2556- mobile

Research Associate

University of Stellenbosch

Kant: 0723782878

Sel 072254 2556\

E-posadres: jhuggins30@gmail.com 